\title{
The analysis of a possibility of construction of a START-STOP system based on an elastic type mechanical starter-accumulator
}

\begin{abstract}
The paper presents research results of a combustion engine ignition start-up process for a city car with the use of a conventional electric starter-motor and with the use of rubber elastic components. The objective of the research work was to compare the ignition dynamics of both concepts and determine the necessary parameters for the rubber elastic components.

The results of the performed research contain the course of torque; the energy and power needed for the ignition are shown on the diagrams. A comparison of these two systems shows that the use of the system with the elastic components having reasonable weight is sufficient enough for a reliable ignition and its mechanical parameters are similar to or even better than the electric starter-motor ignition. Positive results became the basis for the initiation of design works on a concept of a new mechanical START-STOP-system. The preliminary assumption as well as the concept of an integrated mechanical device that combines both the engine starter and the energy accumulator have been presented. The last paragraph describes possible advantages of the new START-STOP system, among which the most important are high energy and cost efficiency as well as its simplicity.
\end{abstract}

Key words: hybrid drivetrain, START-STOP systems, elastic type mechanical accumulators

\section{Analiza możliwości zbudowania systemu START-STOP w oparciu o mechaniczny rozrusznik-akumulator typu sprężystego}

\begin{abstract}
Celem prac badawczych przedstawionych $w$ artykule było określenie parametrów rozruchu silnika spalinowego z użyciem rozrusznika elektrycznego oraz zbudowanie i zbadanie modelowego mechanicznego układu rozruchowego, wykorzystującego gumowe elementy sprężyste. Wyniki badań rozruchu silnika obydwoma sposobami, zawierające przebiegi momentu obrotowego oraz energii i mocy rozruchu, przedstawiono na wykresach. Stwierdzono, że uzyskane wyniki badań wskazują na możliwość zbudowania systemu START-STOP wykorzystującego mechaniczny rozrusznikakumulator. Przedstawiono wstęne założenia konstrukcyjne takiego urządzenia oraz wymieniono spodziewane zalety, z których najważniejsze to prostota i niski koszt oraz wysoka sprawność energetyczna.
\end{abstract}

Słowa kluczowe: napędy hybrydowe, systemy START-STOP, mechaniczne akumulatory energii typu sprężystego

\section{Introduction}

The START-STOP systems serve the purpose of an automatic combustion engine shut-off during each vehicle stop if a predetermined time limit is exhausted and its restart when the driver intends to continue driving. They assure considerable savings in fuel consumption; $10 \%$ on average in urban traffic, and particularly under heavy operating conditions, e.g. while driving in highly congested traffic (traffic jams) or in the case of vehicles driven by postmen (even up to $20 \%$ ). The START-STOP systems, in hybrid drivetrain systems are classified as micro-hybrids due to a relatively low power output of the auxiliary (secondary) power source. Such commercially available systems are of electric type only, which means that the engine start occurs with the use of energy accumulated in an electrochemical battery [9-11]. In spite of the fact that popularity of these systems grows constantly, it should be noted that such systems feature a relatively low watt-hour efficiency (about 60\%), they are rather expensive and constitute a source of ecological burden due to a more intense wear of larger batteries. J. Dzida, the co-author of the paper, for many years has been promoting the idea of a use of mechanical accumulators in hybrid vehicle systems

\section{Wstęp}

Systemy STOP-START służą do automatycznego wyłączania silnika spalinowego w czasie każdego postoju pojazdu, którego czas przekracza ustalony limit, oraz jego ponownego włączenia, gdy kierowca chce kontynuować jazdę. Dają one znaczące oszczędności w zużyciu paliwa - średnio w ruchu miejskim 10\%, a w szczególnie niekorzystnych warunkach eksploatacji, np. jazda w korku, czy użytkowanie samochodu przez listonosza, nawet do $20 \%$. Systemy STOP-START, w grupie hybrydowych układów napędowych, są zaliczane do tzw. micro-hybrid ze względu na stosunkowo małą moc dodatkowego (wtórnego) źródła energii. Dostępne na rynku takie systemy są wyłącznie typu elektrycznego, to znaczy, że uruchomianie silnika spalinowego odbywa się rozrusznikiem elektrycznym z wykorzystaniem energii zgromadzonej w akumulatorze elektrochemicznym [9-11]. Mimo że rośnie popularność tego typu układów, to trzeba zauważyć, że mają one stosunkowo niską sprawnością energetyczną (ok. 60\%), są dość drogie i powodują problemy ekologiczne przez szybsze zużywanie większych akumulatorów. Współautor artykułu, Jan Dzida, od kilku lat przedstawia ideę stoso- 
[1-5]. As we already know, two types of such accumulators are used: kinetic (inertia type) storing mechanical energy in the form of kinetic energy of a gyrating plunger, and elastic type storing energy in the form of potential energy through a deformation of elastic elements. In particular, the accumulators of elastic type are almost forgotten today and are not taken into consideration in the design of hybrid systems. The cited publications point to the necessity of repeated analysis of the feasibility of such type of accumulators in vehicles. In spite of their disadvantages such as low mass density of energy storage, difficulties in control of the torque value in the loading and unloading stages and the presence of high peak values of the elastic tension, it is also worth pointing to the important and forgotten advantages. Among these are: high energy efficiency resulting from a lack of transfer of the mechanical energy into other types of energy (when used in mechanical devices), possibility of a development of high power output in short periods of time and simplicity. As the example of a perfect implementation of the elastic mechanical accumulator we can refer to a cross-bow, which as a small weapon competitive to fire-arms has been used for centuries [12] (Fig. 1).

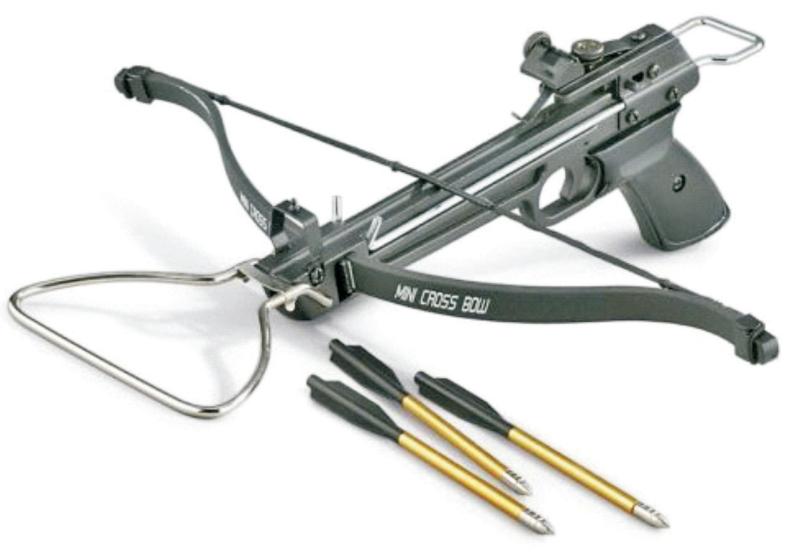

Fig. 1. Contemporary cross-bow as an example of the use of the advantages of elastic type mechanical accumulator

Rys. 1. Wspótczesna kusza jako przykład wykorzystania zalet mechanicznego akumulatora typu sprężystego

When looking for possibilities of utilization of a mechanical type accumulators in hybrid drive systems, the problem of engine start-up is of special significance. One can notice a considerable analogy between shooting of an arrow from a cross-bow and a start-up of a combustion engine. Both these processes take place quickly and consume a given dosage of energy. Such an observation have resulted in initiating by the authors of more detailed analyses of the engine start-up issue with respect to the possibilities of construction of a mechanical start-up system, and as a consequence, a new STARTSTOP system. The authors decided to perform experimental tests, on an test car, which would enable to specify:

- the required value of starting torque and duration of the start-up, wania w hybrydowych układach napędowych pojazdów akumulatorów mechanicznych [1-5]. Jak wiadomo, są dwa rodzaje takich akumulatorów: kinetyczne (inercyjne), które magazynują energię mechaniczną w postaci energii kinetycznej wirującego bezwładnika oraz typu sprężystego, które magazynują energię w postaci potencjalnej przez odkształcenie sprężystych elementów roboczych. Akumulatory typu sprężystego dzisiaj są prawie zapomniane i nie brane pod uwagę w budowie układów hybrydowych. W wymienionych publikacjach wskazuje się na celowość analizy ponownego wykorzystania tych akumulatorów w pojazdach. Mimo ich wad, takich jak mała masowa gęstość magazynowania energii, trudności w sterowaniu wartością momentu obrotowego $\mathrm{w}$ fazie ładowania i rozładowania oraz występowanie dużych szczytowych wartości sił napięcia sprężystego, można również wskazać ważne zalety. Są to: wysoka sprawność energetyczna wynikająca z braku przetwarzania energii mechanicznej na inne rodzaje (przy ich wykorzystywaniu w urządzeniach mechanicznych), możliwość osiągania dużych mocy w krótkich odcinkach czasu i prostota. Jako przykład doskonałego wykorzystania zalet mechanicznego akumulatora sprężystego można podać kuszę, która jako broń strzelecka jest konkurencyjna w odniesieniu do broni palnej i jest stosowana od wielu wieków do dzisiaj [12] (rys. 1).

Przy poszukiwaniu możliwości zastosowania mechanicznych akumulatorów energii typu sprężystego w hybrydowych układach napędowych szczególną uwagę zwraca problem rozruchu silnika. Można zauważyć analogię między wyrzuceniem strzały z kuszy a rozruchem silnika spalinowego. Obydwa procesy trwają krótko i wymagają zużycia określonej dawki energii. To spostrzeżenie spowodowało podjęcie przez autorów niniejszego artykułu dokładniejszych analiz rozruchu silnika spalinowego pod kątem możliwości zbudowania mechanicznego urządzenia rozruchowego, a w dalszej konsekwencji nowego systemu STOP-START. Uznano, że jest bardzo pożądane wykonanie badań doświadczalnych, na przykładowym samochodzie osobowym, które pozwolą określić:

- wymaganą wartość rozruchowego momentu obrotowego i czas trwania rozruchu

- wymaganą energię i moc rozruchu

- orientacyjną masę sprężystych elementów odkształcanych umożliwiających rozruch.

Przyjęto, że uzyskanie tych informacji z badań doświadczalnych pozwoli z dużą pewnością ocenić możliwość zbudowania mechanicznego systemu STOP-START, którego podstawowym zespołem będzie zintegrowany mechaniczny rozrusznik-akumulator.

\section{Badania doświadczalne}

\subsection{Badania rozruchu silnika spalinowego przy użyciu rozrusznika elektrycznego}

Zaplanowane badania doświadczalne potrzebne do wykonania analizy dotyczącej zbudowania nowego systemu STOP-START wykonano w Katedrze Silników Spalinowych i Pojazdów Akademii Techniczno-Humanistycznej w Biel- 
- the required energy and power for the start-up,

- approximate mass of deformable elastic elements which enable the start-up.

It was assumed, that the information obtained in the course of the experimental tests would enable the high certainty level assessment of a possibility of mechanical START-STOP system construction with integrated mechanical starter-accumulator as its main unit.

\section{Experimental tests}

\subsection{Tests of combustion engine start-up with the use of electric starter-motor}

Scheduled experimental tests necessary to analyze the possibility of a construction of a new START-STOP system were accomplished in the Faculty of Combustion Engines and Vehicles in Bielsko-Biala Technical University. A Fiat Seicento SX car powered by a four cylinder, spark ignition $899 \mathrm{ccm}$ engine was selected as the object of the tests.

Firstly, in order to have the results that would serve as a comparison and assessment of the engine start-up with the use of elastic elements, the authors performed a testing of a traditional, electric start-up system. In the course of the tests two parameters in the function of time were recorded: current intensity and, indirectly, engine speed. As a source of energy one implemented a standard automotive battery. The engine start-up was activated traditionally by a driver through an ignition switch. The schematics of the test bed has been shown in Fig. 2.

The engine speed was measured indirectly through a single drive shaft connected to the power transmission system. The road wheel assigned to that drive shaft was disassembled for the testing (Fig. 3). Test car was fitted with a simple differential gear (without increased internal friction), which enabled a free rotation of the wheel hub. Taking the gear ratio values into account, the measurement system enabled a determination of the kinematical parameters of the combustion engine start-up (on engine crankshaft). Such a measurement method was motivated by the fact that the authors' Faculty owns a precise apparatus for the measurement of the speed of the vehicle road wheel the a unification of the proceedings in case of further tests. The measurement of current intensity in the tests was done with the use of a measuring shunt connected in series to the vehicle electrical system to the positive end of the battery.
sku-Białej. Jako obiekt wybrano samochód Fiat Seicento SX napędzany czterocylindrowym silnikiem o zapłonie iskrowym i pojemności skokowej $899 \mathrm{~cm}^{3}$.

W pierwszej kolejności badano tradycyjny rozruch elektryczny, w celu uzyskania wyników, które będą bazą do porównań i oceny rozruchu przy użyciu elementów sprężystych. Podczas badań rejestrowano w funkcji czasu dwa parametry: natężenie prądu i pośrednio prędkość obrotową wału korbowego silnika spalinowego. Źródłem energii elektrycznej do wykonania rozruchu był standardowy akumulator samochodu. Uruchamianie silnika wykonywane było tradycyjnie przez kierowcę za pomocą włącznika zapłonu. Schemat stanowiska badawczego przedstawiono na rys. 2.

Pomiaru prędkości obrotowej wału korbowego silnika dokonywano w sposób pośredni, przez pomiar prędkości obrotowej jednej półosi napędowej samochodu połączonej poprzez mechanizmy przeniesienia napędu $\mathrm{z}$ wałem korbowym. Podczas badań koło na tej półosi napędowej było zdemontowane (rys. 3). Badany samochód miał prosty mechanizm różnicowy (bez zwiększonego tarcia wewnętrznego), co umożliwiało swobodny obrót piasty koła. Układ pomiarowy, przy uwzględnieniu znanych wartości przełożeń mechanicznych, pozwalał określić parametry kinematyczne rozruchu silnika spalinowego (na jego wale korbowym).

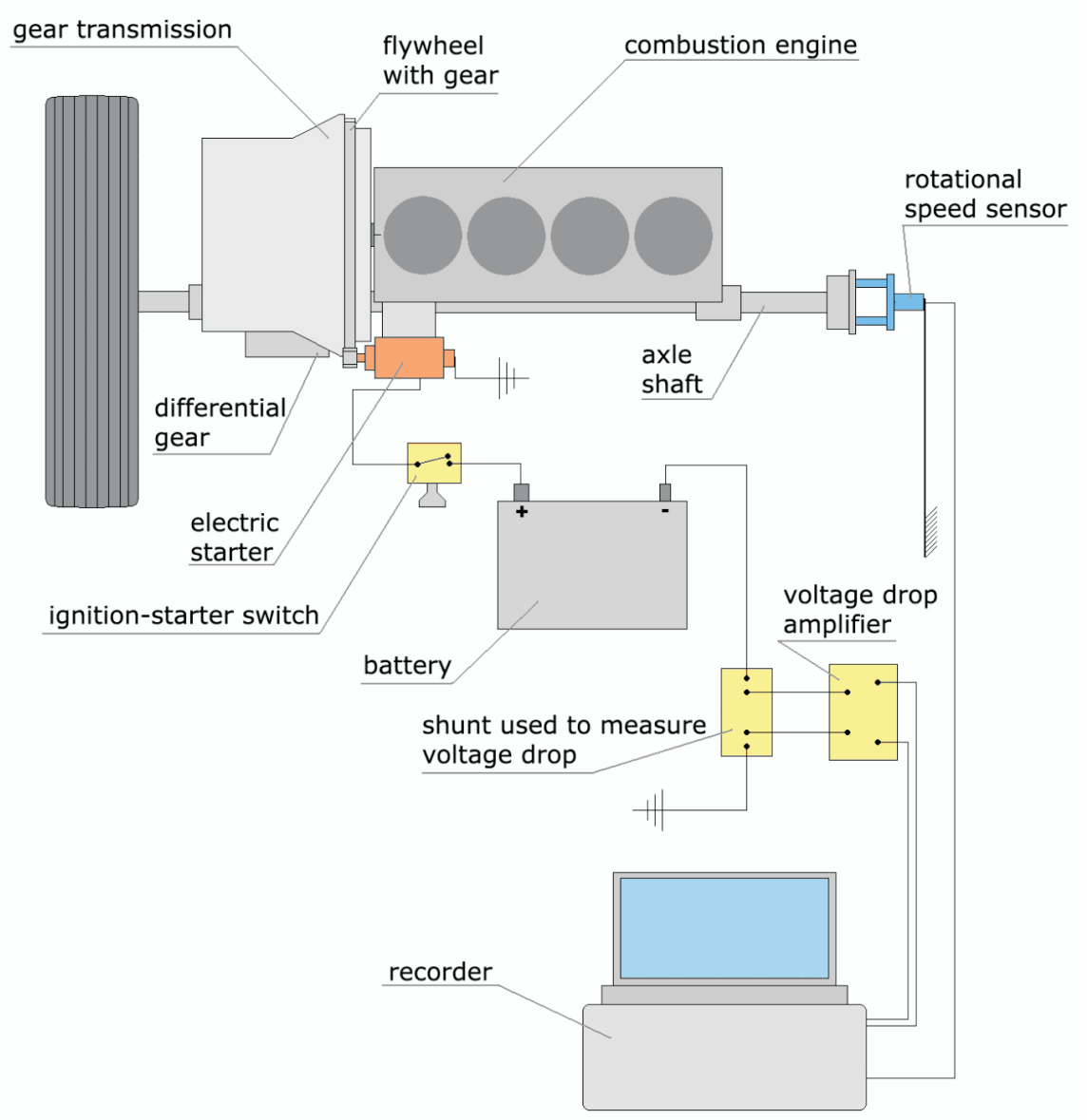

Fig. 2. Schematics of the test bed for the combustion engine electric starter-motor start-up Rys. 2. Schemat stanowiska do badań rozruchu silnika spalinowego za pomoca elektrycznego rozrusznika 


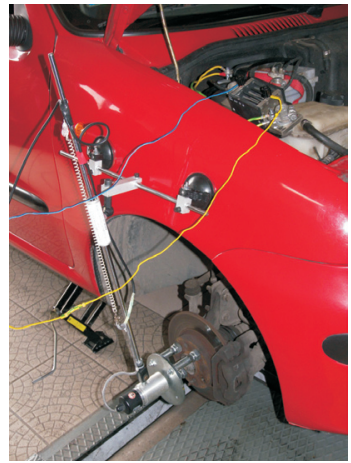

Fig. 3. The view of the wheel hub with the speed sensor and the shunt for the measurement of the starting current

Rys. 3. Piasta koła samochodu z czujnikiem prędkości obrotowej i bocznik do pomiaru pradu rozruchu

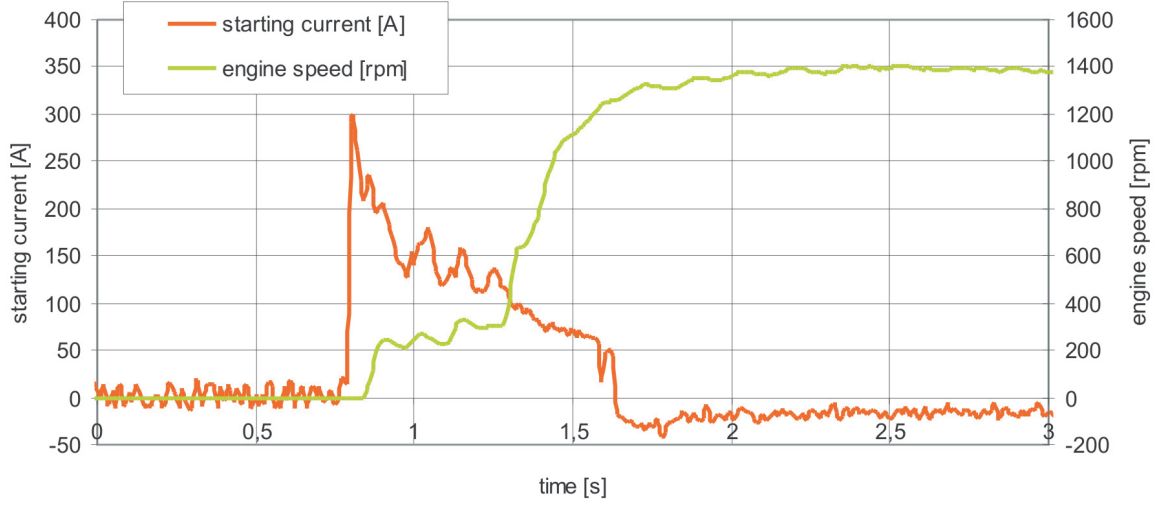

Fig. 4. Exemplary courses of the speed and starting current of the combustion engine crankshaft in the function of time (electric start-up)

Rys. 4. Przykładowe przebiegi prędkości obrotowej i prądu rozruchowego na wale korbowym silnika spalinowego w funkcji czasu (rozruch elektryczny)
The example courses of the speed and current intensity during engine start-up are shown in Fig. 4. In the next analyses, the course of the starting current intensity was substituted with torque calculated with the help of the available characteristics of the starter-motor.

\subsection{The test of the engine start-up with} the use of the elastic elements

The tests were performed with the engine fitted in the car. In order to enable a simple performance of the tests and to avoid any manipulation in the drivetrain system of the car, the authors decided to perform the testing start-ups through a supply of driving force to a single axle drive shaft. The schematics of the model of the mechanical startup system and the implemented measuring apparatus are shown in Fig. 5. A few rubber cables connected in parallel were used as the elastic element. The load generating torque needed for the engine start was applied to the rim of the road wheel. Through the drivetrain system, the torque was transferred to the engine crankshaft. Instead of a complete road wheel (the rim and the tyre), the authors used a properly customized one (Fig. 6). The hook fitted in the rim enabled an automatic disconnection of the rubber cable after the engine start-up. The second end of the rubber cable was connected with a stiff cable. For safety reasons, the cable was reeled on the supporting pulley which enabled to change the direction of the force by $90^{\circ}$. Behind the pulley a load sensor and clamp were positioned, which blocked the cable while wound up in the whole system. A general view of the car and the recording system used is shown in Fig. 7.
Uzasadnieniem tej metody było posiadanie przez Katedrę Silników Spalinowych i Pojazdów precyzyjnej aparatury do pomiaru i rejestracji prędkości obrotowych kół jezdnych samochodu oraz chęć ujednolicenia postępowania z dalszymi badaniami. Pomiaru natężenia prądu w trakcie rozruchu dokonano przy użyciu bocznika pomiarowego podłączonego

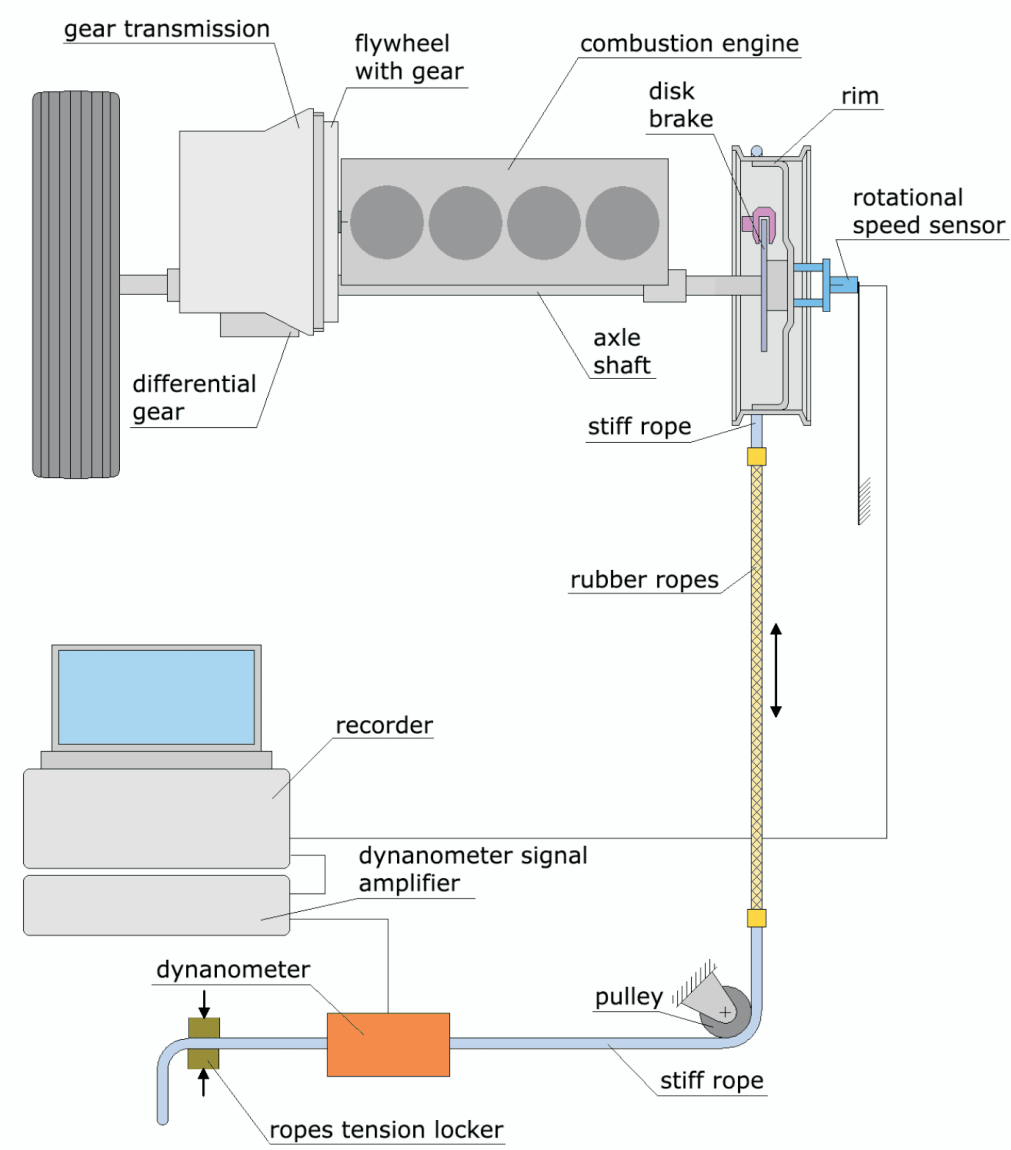

Fig. 5. Schematics of the test bed for the engine start-up with the use of rubber cables Rys. 5. Schemat stanowiska do rozruchu silnika za pomoca lin gumowych 
The tensioning of the rubber cables occurred with a clamped disc brake of the wheel, on which the cable was reeled. In the course of the performance of the testing, the engine was permanently connected with the drivetrain system through an engaged clutch. It should be noted that in a situation of a power transmission originating from the road wheel, the crankshaft rotation speed is increased with respect to the speed of the road wheel rim. It required an application of a bigger starting torque on the rim than in the case of torque applied directly to the engine crankshaft. In order to minimize that phenomenon and to perform the start-up test the authors chose the highest, fifth gear.

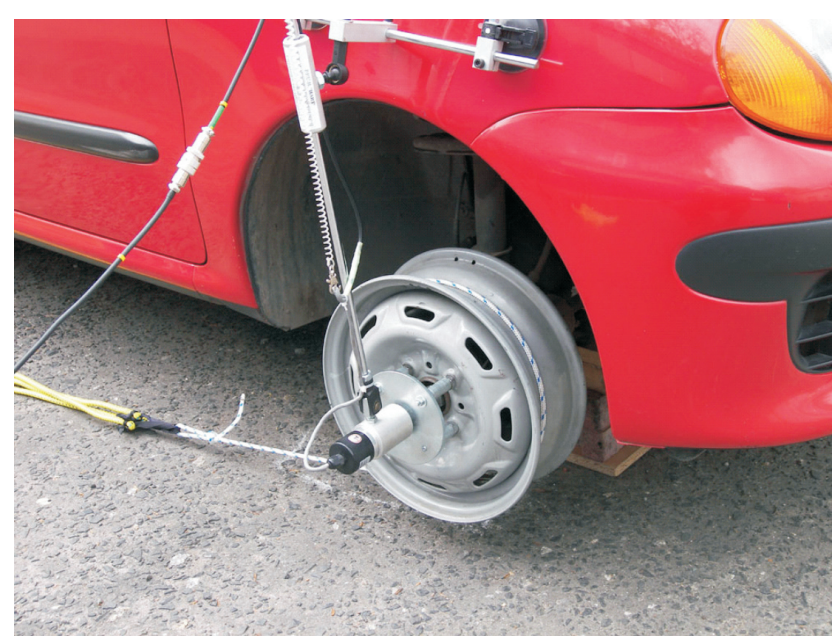

Fig. 6. View of the wheel rim with the speed sensor

Rys. 6. Obręcz koła z czujnikiem prędkości obrotowej

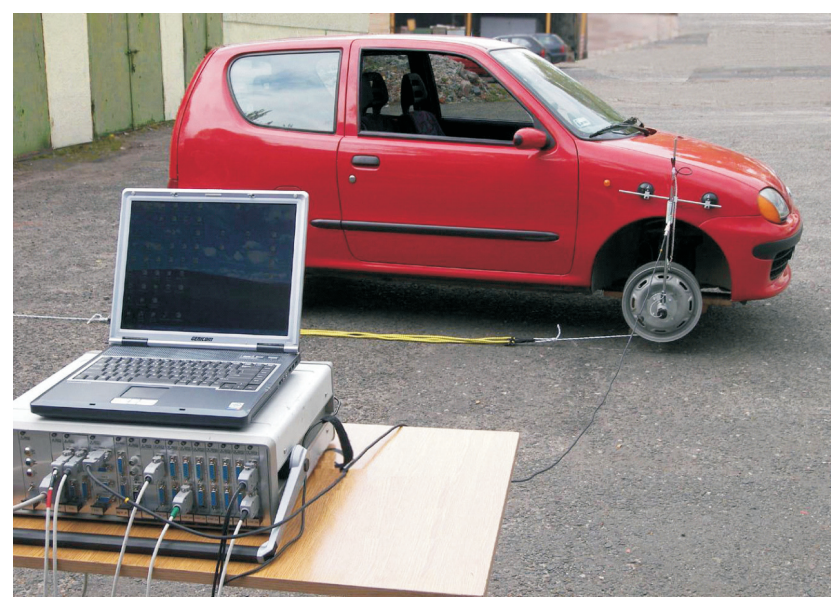

Fig. 7. View of the digital recorder and the car ready for the testing Rys. 7. Cyfrowy rejestrator oraz samochód gotowy do badań

After tensioning of the rubber cables and switching on the ignition the car brake was released. The tension force of the rubber had resulted in a rotation of the wheel rim. In the course of the tests the authors recorded the speed of the rim and the tension force of the rubber cables with the sampling resolution of $0.005 \mathrm{~s}$. The Obtained courses of the speed and torque on the rim were recalculated to the engine crankshaft. Example results of the test, obtained with the use of three rubber cables are presented in Fig. 8. szeregowo do obwodu elektrycznego samochodu po stronie ujemnego bieguna akumulatora.

Przykładowe przebiegi prędkości obrotowej i natężenia prądu podczas rozruchu silnika przedstawiono na rys. 4 . W dalszych analizach przebieg natężenia prądu rozruchowego zastępowano momentem obrotowym, obliczonym przy wykorzystaniu dostępnej charakterystyki rozrusznika.

\subsection{Badania rozruchu silnika spalinowego przy użyciu elementów sprężystych}

Badanie przeprowadzono na silniku zamontowanym w samochodzie. W celu możliwie prostego wykonania badań i uniknięcia ingerencji w układ napędowy samochodu postanowiono wykonywać rozruchy badawcze przez doprowadzenie napędu do jednej półosi. Schemat modelowego mechanicznego układu rozruchowego i zastosowanej aparatury pomiarowej przedstawiono na rys. 5. Jako elementy sprężyste użyto kilka połączonych równolegle lin gumowych. Siła generująca moment obrotowy potrzebny do rozruchu silnika spalinowego przyłożona była do obręczy koła samochodu. Za pośrednictwem układu napędowego moment obrotowy był przekazywany na wał korbowy silnika. Zamiast kompletnego koła składającego się z obręczy i opony użyto odpowiednio przystosowaną obręcz (rys. 6). Zamontowany na obręczy hak umożliwiał samoczynne odłączenie się sznura po uruchomieniu silnika. Drugi koniec lin gumowych również połączono z nieelastycznym sznurem. Ze względów bezpieczeństwa sznur opasał rolkę podtrzymującą, która pozwalała na zmianę o $90^{\circ}$ kierunku działania siły. Za rolką umieszczono czujnik siły oraz zacisk, który unieruchamiał sznur w stanie napięcia całego układu. Samochód i zastosowaną aparaturę rejestrującą przedstawiono na rys. 7 .

Napinanie lin gumowych następowało przy zaciśniętym hamulcu tarczowym koła, na który nawinięty był sznur. Podczas przeprowadzania badania silnik był stale połączony układem napędowym przez włączone sprzęgło. Należy zauważyć, że przy napędzie pochodzącym od koła jezdnego prędkość obrotowa wału korbowego silnika jest zwiększana względem prędkości obrotowej obręczy koła. Wymagało to przyłożenia większego rozruchowego momentu obrotowego do obręczy koła niż w przypadku, gdyby moment ten był przykładany bezpośrednio do wału korbowego silnika. Aby możliwie zminimalizować to zjawisko, do przeprowadzania próby rozruchu wybrano najszybszy piąty bieg.

Po napięciu gumowych lin i włączeniu zapłonu silnika następowało zwolnienie hamulca samochodu. Siła napięcia gumy powodowała obrót obręczy koła. Podczas badania rejestrowano prędkość obrotową obręczy oraz siłę napięcia lin gumowych z okresem próbkowania rejestratora $0,005 \mathrm{~s}$. Otrzymane przebiegi prędkości i momentu obrotowego na obręczy koła przeliczano na wał korbowy silnika. Przykładowe wyniki badań, uzyskane przy zastosowaniu trzech lin gumowych, przedstawiono na rys. 8 .

Wykonano również badania rozruchu silnika dla wzmocnionej wersji gumowego układu rozruchowego. Większą energię rozruchu osiągnięto, zwiększając moment rozruchowy drogą równoległego dołączenia dodatkowych dwóch lin 
Additionally, the authors also performed the tests of the engine start-up for a reinforced version of the rubber start-up system. Higher starting energy was developed, increasing the starting torque by a parallel connection of two additional rubber cables and through an increased $50 \%$ wrapping angle of the cable on the wheel rim. It enabled a lengthening of the angular path of the crankshaft, on which the increased starting torque operated. In the diagrams presented in the next chapter the test results of the reinforced version are marked as modified rubber start-up.

A more detailed presentation of the tests of various variants of the start-up with the use of both rubber cables and an electric starter-motor are presented in [6].

\subsection{Comparison of tested systems of the engine start-up}

A variety of aggregated comparison diagrams with the test results of various types of the start-up (Figs. 9, 10 and 11) have been prepared. The diagrams have revealed their common features as well as differences in individual start-ups. Among the common features we can list a similar time of the startup (below 1s), whereas as anticipated, the use of more rubber elements increased the starting torque and shortened the duration of the startup. An electric start-up can be characterized by a decreasing and strongly pulsating curve of the starting torque, while the curve of the crankshaft speed (Fig. 4) exhibits small pulsations. In the case of the start-up with the use of rubber cables, the curves of the torque do not show any pulsations, while the curves of the crankshaft speed feature a higher oscillation of values.

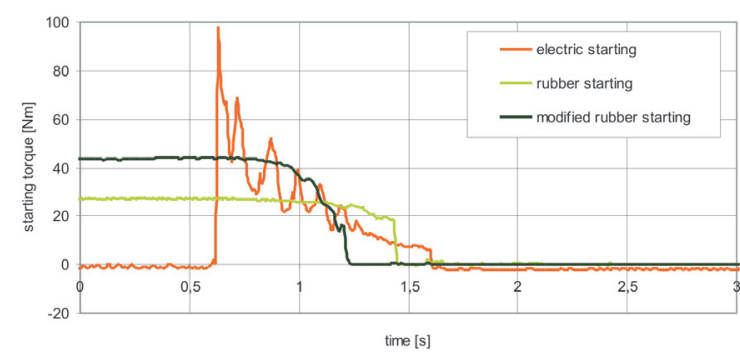

Fig. 9. A comparison of the course of the starting torque for various types of the start-up in the function of time

Rys. 9. Porównanie przebiegu momentu rozruchowego dla różnych rodzajów rozruchu $w$ funkcji czasu

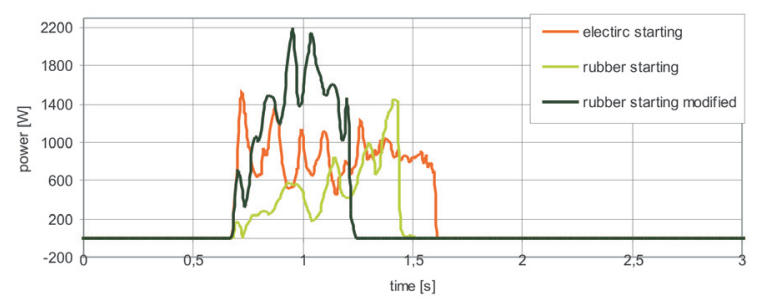

Fig. 10. A comparison of the course of the power output for various types of the start-up in the function of time

Rys. 10. Porównanie przebiegu mocy rozruchowej dla różnych rodzajów rozruchu w funkcji czasu

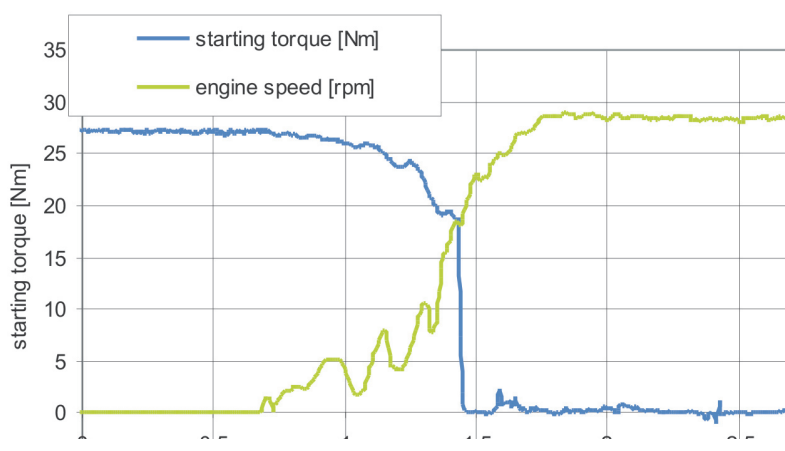

Fig. 8. Courses of the speed and starting torque on the engine crankshaft in the function of time (start-up with the use of rubber cables)

Rys. 8. Przebieg prędkości obrotowej i momentu rozruchowego na wale korbowym silnika spalinowego w funkcji czasu (rozruch przy użciu lin gumowych)

gumowych oraz przez powiększenie kąta opasania sznura na obręczy koła o 50\%. Pozwoliło to wydłużyć drogę kątową wału korbowego, na której działał teraz dodatkowo zwiększony moment rozruchowy. Na wykresach (rys. 10 i 11) wyniki badań wersji wzmocnionej oznaczono jako rozruch gumowy zmodyfikowany.

Szczegółowiej badania różnych wariantów rozruchu z użyciem lin gumowych i rozrusznika elektrycznego oraz opis metody $\mathrm{i}$ aparatury pomiarowej przedstawiono $\mathrm{w}$ [6].

\subsection{Porównanie zbadanych systemów rozruchu}

Wykonano zestawieniowe wykresy porównawcze wyników badań różnych rodzajów rozruchów (rys. 9, 10 i 11). Wykazały one ich cechy wspólne i różnice w poszczególnych rozruchach. Do cech wspólnych należy zaliczyć zbliżony czas rozruchu (poniżej 1s), przy czym, zgodnie z przewidywaniami, użycie większej liczby elementów gumowych zwiększyło rozruchowy moment obrotowy i skrócił się czas rozruchu. Rozruch elektryczny charakteryzuje się opadającą i mocno pulsującą linią momentu rozruchowego, zaś krzywa prędkości obrotowej (rys. 4) wykazuje małe pulsacje. W sytuacji rozruchu przy użyciu lin gumowych krzywe momentu nie wykazują pulsacji, za to krzywe prędkości obrotowej wału korbowego (rys. 8) mają duże wahania wartości.

Te różnice w przebiegach krzywych momentów i prędkości obrotowych wynikają z innego charakteru współpracy rozrusznika elektrycznego i napędu gumowego z wałem korbowym silnika, na który działa cyklicznie zmienne obciążenie wynikające z suwów sprężania w poszczególnych cylindrach.

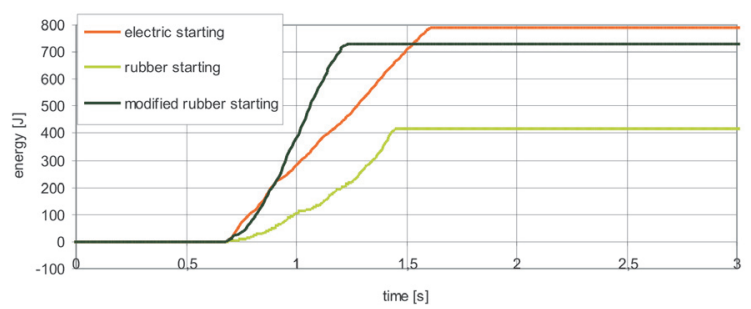

Fig. 11. A comparison of the starting energy for various types of the start-up in the function of time

Rys. 11. Porównanie energii rozruchu dla różnych rodzajów rozruchu w funkcji czasu 
Such differences in course of torque and speed result from different character of the "mating" of the electric starter-motor and the rubber drive with the engine crankshaft being under the effect of cyclic and changing load due to the compression strokes in individual cylinders.

The power outputs presented in Fig. 10 have shown that the highest power output with transient value reaching up to $2200 \mathrm{~W}$ was developed in the case of the modified rubber start-up system. Mechanical energy of the start-up (Fig. 11) in the case of electric startup amounted to approximately 790 $\mathrm{J}$, whereas for the rubber start-up types to $730 \mathrm{~J}$ ( 5 cables) and to about $420 \mathrm{~J}$ ( 3 cables). The performed modification of the pack of rubber cables and the obtained changes in the starting process point at a big potential of the shaping of the course of the very startup process in the case of such a type of drive.

\section{Design assumptions of the START-STOP system with an electric type mechanical accumulator}

The performed tests of the combustion engine start-up with the use of the electric starter-motor and with the use of elastic rubber elements have yielded good recognition of that process for both systems. An important result itself was the fact of a performed combustion engine start-up with the use of the rubber elements having relatively low mass equal to about $0.6 \mathrm{~kg}$. The obtained results enable pretty accurate formulation of the design assumptions and requirements necessary to be fulfilled in a new START-STOP system with an elastic type mechanical energy accumulator. For the first development stage of such a design solution one assumes the presence, except standard electric starter-motor, of an additional mechanical starter in the system performing the function of the accumulator. The starter-accumulator shall be connected with the engine crankshaft with an PolyV belt.

The following design assumptions were taken while building the mechanical starter:

- the torque characteristics in the function of crankshaft speed (likewise in the function of time) should have a decreasing nature and should have a form similar to a triangle,

- the duration of the start-up should be 5-7 crankshaft revolutions and should be terminated with the discharge of the accumulator,

- it is required, that loading of the accumulator occurs at the torque having a value of 3-5 times less than during the unloading, which will reduce the engine load during its switch off,

- the required starting energy, for the tested engine of $900 \mathrm{ccm}$ capacity, to assure a short time of the start-up, should remain on the level not less than $700 \mathrm{~J}$.

In Fig. 12 a simplified course of the mechanical starteraccumulator torque is presented, transferred into the engine crankshaft, in the phase of loading and unloading.

The authors consider that today's state of technology, also in the area of elastically deformable materials, enables a development of such a starter system in a short time. Obviously, it is necessary to perform an optimization of the
Przedstawione na rysunku 10 zmierzone moce wykazały, że w przypadku gumowego rozruchu zmodyfikowanego osiągnięto największą moc, o wartościach chwilowych dochodzących do $2200 \mathrm{~W}$. Energia mechaniczna rozruchu (rys. 11) dla rozruchu elektrycznego wynosiła około $790 \mathrm{~J}$, zaś dla rozruchów gumowych $730 \mathrm{~J}$ (5 lin) i około $420 \mathrm{~J}$ (3 liny). Wykonana modyfikacja zespołu lin gumowych i uzyskane zmiany w procesie rozruchu wskazują na duże możliwości w kształtowaniu jego przebiegu przy tym rodzaju napędu.

\section{Założenia projektowe systemu STOP-START z akumulatorem mechanicznym typu sprężystego}

Wykonane badania rozruchu silnika spalinowego przy użyciu rozrusznika elektrycznego oraz sprężystych elementów gumowych pozwoliły na dobre rozpoznanie tego procesu w obu przypadkach. Ważnym wynikiem było samo dokonanie rozruchu silnika spalinowego przy użyciu elementów gumowych o stosunkowo niewielkiej masie około $0,6 \mathrm{~kg}$. Otrzymane wyniki pozwalają dość dokładnie sformułować założenia projektowe i wymagania, które powinny być spełnione w nowym systemie STOP-START z mechanicznym akumulatorem energii typu sprężystego. W pierwszym etapie prac nad takim rozwiązaniem zakłada się, że w systemie będzie występował, poza standardowym rozrusznikiem elektrycznym, dodatkowy mechaniczny rozrusznik pełniący równocześnie funkcję akumulatora. Rozrusznik-akumulator będzie połączony z wałem korbowym silnika przy użyciu paska wieloklinowego.

Przyjęto następujące założenia projektowe do jego budowy:

- charakterystyka momentu obrotowego w funkcji obrotów wału (podobnie w funkcji czasu) powinna być opadająca i mieć postać zbliżoną do trójkąta,

- rozruch powinien trwać 5-7 obrotów wału korbowego i zakończyć się rozładowaniem akumulatora,

- pożądane jest, aby ładowanie rozrusznika akumulatora odbywało się przy momencie obrotowym o wartości 3-5 razy mniejszym niż przy rozładowaniu, co zmniejszy obciążenie silnika spalinowego przy jego wyłączaniu,

- wymagana energia rozruchu, dla przykładowego silnika o pojemności $900 \mathrm{~cm}^{3}$, powinna wynosić nie mniej niż $700 \mathrm{~J}$, aby zapewnić krótki czas rozruchu.

Na rysunku 12 przedstawiono uproszczony przebieg momentu obrotowego mechanicznego rozrusznika-akumulatora, przeliczony na wał korbowy silnika, w fazie ładowania i rozładowania.

Autorzy uważają, że aktualny poziom technologii, również w zakresie materiałów sprężyście odkształcalnych, pozwala w krótkim czasie opracować taki rozrusznik. Oczywiście niezbędne będzie wykonanie optymalizacji konstrukcji obejmującej ogólny układ (architekturę), parametry geometryczne i dobór materiałów elementów sprężystych. Dotychczasowe prace wykazują, że postać konstrukcyjna rozrusznika-akumulatora może być zbliżona do obecnie stosowanego alternatora, bądź pompy układu klimatyzacji. Zakładany schemat blokowy mechanicznego rozrusznika-akumulatora przedstawia rys. 13 . 
design comprising the general layout (architecture), geometrical parameters and selection of materials for the elastic elements. Up-to-now projects show that the design shape of the starter-accumulator could be similar to an alternator used today, or a pump from the air conditioning system. The assumed block diagram of the mechanical starter-accumulator is shown in Fig. 13.

Possible to implement elastic elements which can be taken into consideration are helical or spiral springs. The authors consider, however, that modern materials of rubber type should be selected for the process, due to a mass density of energy storage which is several-times higher. It should also be noted that the proposed starter-accumulator is to be a mechatronic device, capable to cooperate with electronic control modules of vehicles. It denotes, that the starter-accumulator shall be equipped with electronic sensors determining, for instance, the state of its loading and electronically controlled sub-assemblies such as clutches activating the loading and unloading phases.

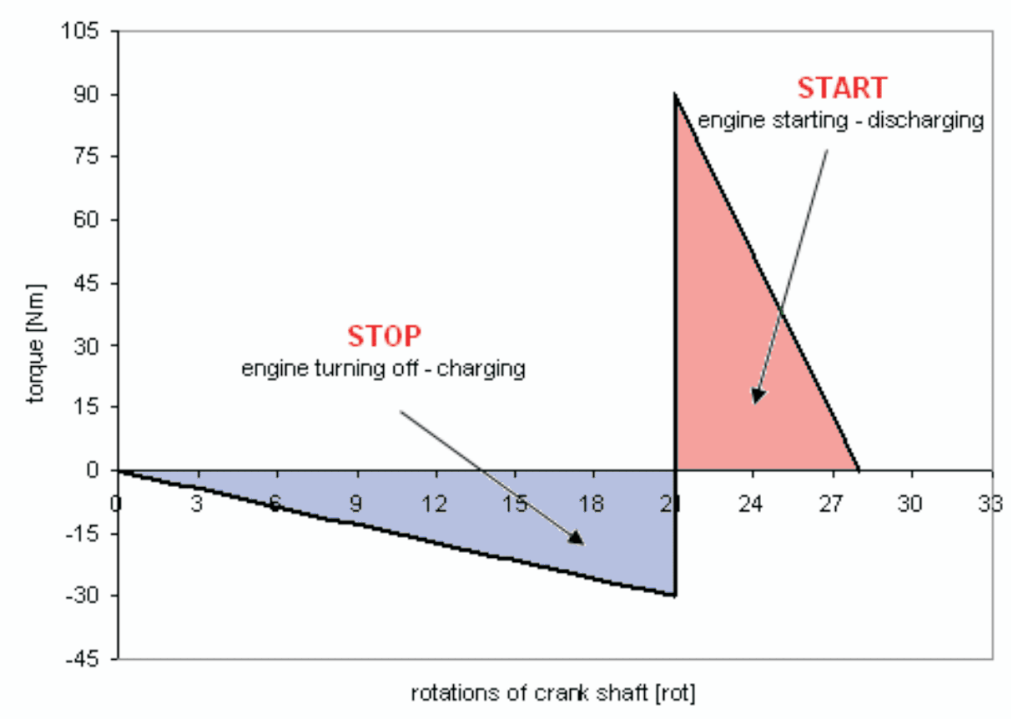

Fig. 12. The assumed course of the torque of the START-STOP starter-accumulator system during a single operational cycle (on engine crankshaft)

Rys. 12. Zakładany przebieg momentu obrotowego rozrusznika-akumulatora systemu STOP-START w jednym cyklu działania (na wale korbowym silnika spalinowego)

Jako możliwe do zastosowania elementy sprężyste można brać pod uwagę również stalowe sprężyny śrubowe lub spiralne. Autorzy uważają jednak, że należy preferować

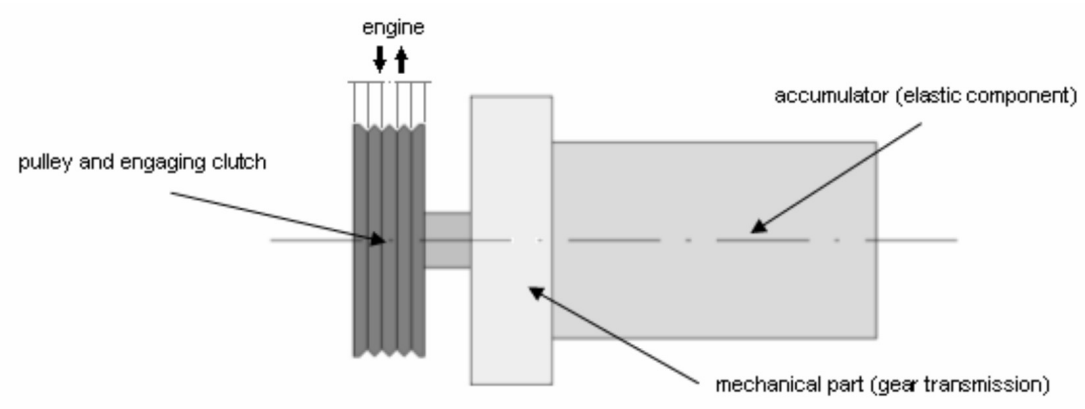

Fig. 13. Block diagram of the starter-accumulator

Rys. 13. Schemat blokowy docelowego rozrusznika-akumulatora nowoczesne materiały typu gumowego, ze względu na kilkakrotnie większą masową gęstość magazynowania energii. Trzeba również zauważyć, że proponowany rozrusznik-akumulator będzie urządzeniem mechatronicznym, zdolnym do współpracy z elektronicznym modułem sterującym napędem samochodu. Oznacza to, że rozrusznik-akumulator będzie wyposażony w elektroniczne czujniki określające, na przykład stan jego naładowania oraz sterowane sygnałem elektrycznym podzespoły, takie jak sprzęgła załączające jego ładowanie i rozładowanie.

\section{Final remarks}

The performed experimental tests pointed at an easiness of the engine starting operation with the use of a simple package of stretched rubber cables. It confirms the possibility of construction of a mechanical START-STOP system at least for small passenger cars. Basing the proposed system on the elastic type mechanical accumulator of one can attain many advantages.

The anticipated advantages are as follows:

- low cost of the starter-accumulator including its complete system, resulting from a usage of well known and cheap technologies (enables the use of such systems in small and cheap vehicles),

- additional reduction of fuel consumption - as compared with electric systems - being the result of a higher general

\section{Uwagi końcowe}

Wykonane badania doświadczalne wykazały łatwość dokonania rozruchu silnika spalinowego przy użyciu prostego zespołu naciągniętych lin gumowych. Przekonuje to o możliwości zbudowania, co najmniej do małych samochodów osobowych, mechanicznego systemu STOP-START. Oparcie proponowanego systemu na mechanicznym akumulatorze typu sprężystego umożliwia osiągnięcie wielu korzyści.

Spodziewane zalety są następujące:

- niski koszt rozrusznika-akumulatora i całego systemu, wynikający z wykorzystania dobrze znanych i tanich technologii, co umożliwi rozszerzenie stosowania tego typu układów na pojazdy małe i tanie,

- dodatkowe zmniejszenie zużycia paliwa, w stosunku do systemów elektrycznych, spowodowane wyższą 
efficiency and lacking conversion of mechanical energy into other types of energy,

- easiness and low cost of remanufacturing of the starteraccumulator through replacement of rubber elastic elements,

- lacking ecology problems connected with the disposal of used up elements storing the energy, due to a long time knowledge of the material components.

The above mentioned advantages are possible to be attained, provided that innovative and careful approach is taken to develop the starter-accumulators in order to circumvent the problems connected with the elastic type mechanical energy accumulator specified at the beginning of the paper. Important incentives for the development of such type of design is the KERS hybrid systems [5 and 8] recently introduced in the $\mathrm{F} 1$ racing cars, which utilize the kinetic type mechanical energy accumulators. It seems that it is a harbinger of a possibility of a changing direction in further development of hybrid drive systems. On such background it is possible to express a conviction that the START-STOP systems with mechanical starter-accumulators (elastic type) can be and should be developed in the nearest future. The authors have already undertaken a work on the final design of the system of such starter-accumulator and are hopeful that more extensive research-development work in this area shall be commenced soon. sprawnością ogólną wywołaną brakiem przetwarzania energii mechanicznej na inne rodzaje,

- łatwość i niski koszt regeneracji rozrusznika-akumulatora przez wymianę gumowych elementów sprężystych,

- brak problemów ekologicznych z utylizacją zużytych elementów akumulujących energię, ze względu na znane od dawna komponenty materiałowe.

Powyższe zalety będzie można osiągnąć pod warunkiem starannego i nowatorskiego podejścia do opracowania konstrukcji rozrusznika-akumulatora, w której muszą być pokonane lub ominięte wymienione we wstępie problemy mechanicznych akumulatorów energii typu sprężystego. Ważną zachętą do rozwijania tego rodzaju konstrukcji jest wprowadzenia w bieżącym roku do samochodów Formuły 1 systemów hybrydowych KERS [5, 8], wykorzystujących mechaniczne akumulatory energii typu kinetycznego. Wydaje się, że sygnalizuje to możliwość zmiany kierunku dalszego rozwoju napędów hybrydowych. Na tym tle można wyrazić przekonanie, że system STOP-START z rozrusznikiemakumulatorem mechanicznym, tym razem typu sprężystego, może i powinien powstać w krótkim czasie. Autorzy podjęli już prace nad docelowym układem konstrukcyjnym takiego rozrusznika-akumulatora i mają nadzieję, że niedługo będą uruchomione szersze prace badawczo-rozwojowe na ten temat.

Paper reviewed

\section{Bibliography/Literatura}

[1] Dzida J.: The concept of hybrid power transmission system for automobilies. Sustainable and Safe Surface Transport Conference. Warszawa 2005.

[2] Dzida J.: The research of the new idea of hybrid power transmission with the mechanical accumulator. Scientific Journal of Automotive Research and Development Centre BOSMAL, no. 34 (IV/2006), Bielsko-Biała 2006.

[3] Dzida J.: Współdziałanie dwóch źródeł energii w hybrydowych układach napędowych samochodów. Technical Projects nr 1/2006, Wydawnictwo Salve, Bielsko-Biała 2006.

[4] Dzida J.: The analysis of combustion engine and spring-loaded accumulator's cooperarion in hybryd drive system of vehicle. International Congress of Combustion Engines 2007, Kraków 2007.

[5] Dzida J.: The New mechanical accumulators of energy for hybryd vehicles. Scientific Journal of Automotive Research and Development Centre BOSMAL, no. 40 (II/2008), Bielsko-Biała 2008.

[6] Dzida J.M.: The study of the possibility of build the STARTSTOP device for city passenger car, based on elastic medium.

Mr. Jan Dzida, DEng. - doctor in the Department of Internal Combustion Engines and Vehicles at University of Bielsko-Biała.

Dr inż. Jan Dzida - adiunkt w Katedrze Silników Spalinowych i Pojazdów Akademii Techniczno-Humanistycznej w Bielsku-Biatej.

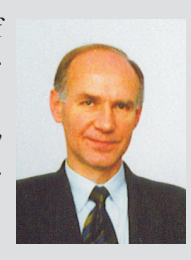

Diploma Thesis, Department of Mechanical Engineering and Computer Science at University of Bielsko-Biała, major advisor Romaniszyn K., Bielsko-Biała 2008.

[7] Dzida J., Dzida J.M.: Combustion engine start-up testing with use of elastic elements, and a concept of mechanical STARTSTOP system. International Congress of Combustion Engines 2009, Opole 2009.

[8] Hilton J.: Braking Energy Storage and Recovery - Flywheel for Motorsport Application, ATZ Autotechonology 3/2008, marzec 2008.

[9] Łągiewicz J.: Mikrohybrydy - system Stop\&Start, Auto-Technika Motoryzacyjna nr 11/2007, Wydawnictwo Moto Media Forum, Legionowo 2007.

[10] Merkisz J., Pielecha I.: Alternatywne napędy pojazdów. Wydawnictwo Politechniki Poznańskiej, Poznań 2006.

[11] Merkisz J., Zieliński A.: Analysis of development of hybrid powertrains systems in cars. Scientific Journal of Automotive Research and Development Centre BOSMAL, no. 27 (I/2005), Bielsko-Biała 2005.

[12] Commercial material of MN Crossbow.

Mr. Jakub Mikołaj Dzida, Eng. - employee of Engine Testing Laboratory at R\&D Centre BOSMAL in Bielsko-Biała.

Mgr inż. Jakub Mikołaj Dzida - starszy referent ds. badań w Laboratorium Badań Silników Spalinowych w OBR SM BOSMAL w Bielsku-Białej.

e-mail: jakub.dzida@bosmal.com.pl 